\title{
From DDT to Integrated Pest Management - a significant role of Scientific Sessions of the Institute of Plant Protection
}

\author{
Od DDT do integrowanej ochrony roślin \\ - znacząca rola Sesji Naukowych Instytutu Ochrony Roślin
}

\author{
Danuta Sosnowska*, Stefan Pruszyński
}

\begin{abstract}
Summary
Progress in the development of plant protection over the last 55 years has been consistently discussed during the Scientific Sessions of the Institute of Plant Protection. It is worth emphasizing that the First Scientific Session was organized at the time of the beginning of an era criticizing chemical plant protection, however, DDT and its derivates were still common in use. The last Scientific Sessions were mainly dedicated to the initiatives of implementation and dissemination of Integrated Pest Management while the current Scientific Session discusses the first results of this protection system in Poland. Along with the development of some new concepts and strategies regarding plant protection implementation in our country, the Scientific Sessions have been involved in a longterm process of changes - "From DDT to Integrated Pest Management".
\end{abstract}

Key words: Integrated Pest Management; Scientific Sessions of the Institute of Plant Protection

\section{Streszczenie}

Przedstawiono zmiany w ochronie roślin, jakie miały miejsce w ciągu ostatnich 55 lat, które zaprezentowano na organizowanych corocznie od 1961 r. Sesjach Naukowych Instytutu Ochrony Roślin (IOR). Pierwsza konferencja zbiegła się w czasie z początkiem krytyki chemicznej ochrony roślin, ale nadal powszechnym stosowaniem DDT i innych substancji czynnych z tej grupy chemicznej. Przewodnimi tematami ostatnich Sesji Naukowych było przygotowanie do wdrożenia i upowszechnienia integrowanej ochrony roślin, a w trakcie obecnej zostały omówione pierwsze wyniki realizacji tego systemu ochrony w Polsce. Wraz z rozwojem koncepcji i strategii realizacji zadań ochrony roślin w Polsce Sesje Naukowe IOR przebyły długą drogę „Od DDT do integrowanej ochrony roślin”.

Słowa kluczowe: Integrowana Ochrona Roślin; Sesje Naukowe Instytutu Ochrony Roślin

Instytut Ochrony Roślin - Państwowy Instytut Badawczy

Władysława Węgorka 20, 60-318 Poznań

*corresponding author: Danuta.Sosnowska@iorpib.poznan.pl 


\section{Wstęp / Introduction}

W roku 1956 decyzją Ministra Rolnictwa, Dyrekcja utworzonego w 1951 roku Instytutu Ochrony Roślin (IOR) została przeniesiona z Warszawy do nowo wybudowanego Oddziału w Poznaniu, a na stanowisko Dyrektora został powołany prof. dr hab. Władysław Węgorek.

Wraz z Dyrekcją do Poznania przeszedł zespół pracowników z Puław, a w ramach dalszej reorganizacji do Poznania trafiali pracownicy likwidowanych Oddziałów Instytutu z: Bydgoszczy, Gorzowa i Wrocławia. W ciągu kilku lat Instytut Ochrony Roślin w Poznaniu, dzięki wybudowaniu nowych budynków laboratoryjnych oraz wzmocnieniu kadry naukowej i technicznej, stał się prężną jednostką naukową przygotowaną na podejmowanie i rozwiązywanie występujących problemów ochrony roślin w polskim rolnictwie.

W lutym 1961 roku prof. W. Węgorek zorganizował Konferencję naukową z okazji 10-lecia Instytutu, poświęconą omówieniu dorobku Instytutu oraz realizowanym w Instytucie kierunkom badawczym. Przy dużym zainteresowaniu ze strony jednostek naukowych, służb ochrony roślin i administracji konferencje były organizowane w latach następnych, przyjmując nazwę Sesji Naukowych Instytutu Ochrony Roślin. Dorobek naukowy i upowszechnieniowy Sesji został omówiony w specjalnym wydawnictwie przygotowanym z okazji 50. Sesji (Mrówczyński 2010), a celem obecnego opracowania było przedstawienie tematyki integrowanej ochrony roślin podejmowanej w obradach kolejnych Sesji.

\section{Uwarunkowania organizacji pierwszych Sesji Naukowych IOR / Factors affecting the organization of first Institute of Plant Protection Scientific Sessions}

Analizując obecnie przyczyny bardzo dużego zainteresowania i licznego udziału uczestników w pierwszych Sesjach Naukowych IOR należy podkreślić, że podjęcie organizacji Sesji miało miejsce w okresie niezwykle ważnych i dynamicznych przemian zachodzących w światowej i polskiej ochronie roślin.

W roku 1959, a więc na dwa lata przed pierwszą Sesją, ukazała się publikacja wprowadzająca do słownika ochrony roślin pojęcie ,integracja” (Stern i wsp. 1959).

W światowej ochronie roślin kończył się okres fascynacji chemiczną ochroną roślin, a rozpoczął się okres bardzo ostrej krytyki tej metody. Metcalf (1980) rozwój ochrony roślin po II Wojnie Światowej określił jako Wiek Pestycydów dzieląc go na ery:

entuzjazmu - 1946-1962,

zwątpienia - 1962-1976,

integracji - od 1976.

Jako początek ery zwątpienia Metcalf (1980) przyjął wydanie w roku 1962 książki Rachel L. Carson „Silent Spring” („Milcząca wiosna”) (Carson 1962) będącej zbiorem informacji poważnie oskarżającym chemiczną ochronę roślin za niekorzystny, uboczny wpływ pestycydów na człowieka i środowisko.
Zmieniło się podejście do chemicznej ochrony roślin również w naszym kraju. Jak wspomina prof. J. Boczek (Boczek 2010) w czasie obrad pierwszej Sesji w 1961 roku doszło do bardzo ostrej dyskusji dotyczącej zakresu i potrzeby stosowania chemicznych środków ochrony roślin.

W Polsce po pierwszych pojawach i nalocie z Europy stonki ziemniaczanej (Leptinotarsa decemlineata Say) już w roku 1947 Zakłady Chemiczne „Azot” w Jaworznie podjęły produkcję DDT, a następnie innych środków, osiągając w roku 1955 produkcję na poziomie 2000 ton substancji czynnych. Do stosowania dopuszczono dużą grupę środków pylistych o niskiej zawartości substancji czynnych, ale stanowiących największe zagrożenie dla środowiska przez łatwość znoszenia (Pruszyński i Moszczyński 1992).

W roku 1961 weszła w życie nowa ustawa wprowadzająca m.in. obowiązek i warunki dopuszczenia w Polsce środków ochrony roślin do obrotu i stosowania - rejestracji.

Przy dużym rozdrobnieniu gospodarstw brakowało opryskiwaczy do zwalczania stonki na polach o małej powierzchni i były przypadki, że do wykonania zabiegu użytkownicy posługiwali się konewką, czy opylając wykorzystywali pończochę.

Następowały zmiany w organizacji służby ochrony roślin i jej podporządkowaniu różnym organom administracji.

Pozostała bardzo pilna potrzeba szerokiego i szybkiego przekazu wszystkim zainteresowanym informacji o zachodzących zmianach, wynikach badań naukowych, nowych tendencjach i ukierunkowaniu rozwoju ochrony roślin, a także decyzjach administracyjnych oraz miejscu i obowiązkach służby ochrony roślin w upowszechnianiu wyników badań i nowych obowiązujących zaleceń.

Rolę przekazu tych zmian przejęły na siebie Sesje Naukowe Instytutu Ochrony Roślin z założenia będące spotkaniem nauki i praktyki ochrony roślin.

Zrozumiałym stał się liczny udział w spotkaniach sesyjnych przedstawicieli różnych grup zawodowych związanych $\mathrm{z}$ ochroną roślin oraz uznane znaczenie Sesji w ukierunkowaniu rozwoju ochrony roślin w naszym kraju.

\section{Integrowana ochrona roślin w tematyce Sesji Naukowych Instytutu Ochrony Roślin - Państwowego Instytutu Badawczego (IOR - PIB) / Integrated Plant Protection in Scientific Sessions of Institute of Plant Protecion - National Research Institute}

Omawiając tematykę związaną z integrowaną ochrona roślin prezentowaną w obradach Sesji Naukowych IOR nie można ograniczyć się do wystąpień poświęconych jedynie temu zagadnieniu, ale należy również uwzględnić referaty ukierunkowane na tworzenie warunków do opracowania integrowanych programów ochrony oraz zapobiegania ubocznym skutkom stosowania chemicznych środków ochrony roślin. 
W czasie obrad pierwszej Sesji w 1961 r. został zaprezentowany referat (Piekarczyk 1961) poświęcony podstawom naukowym i organizacji prognoz i sygnalizacji organizmów szkodliwych. Dziś wiadomo, że monitoring występowania agrofagów jest jedną $\mathrm{z}$ podstaw realizacji integrowanych programów ochrony roślin. Podjęta również została tematyka odporności szkodników na chemiczne środki ochrony roślin (Ląkocy 1961), a więc jednego z najpoważniejszych problemów, jaki towarzyszy ochronie roślin do czasów obecnych, a zapobieganie wytwarzania odporności jest jednym $\mathrm{z}$ zadań integrowanej ochrony roślin.

W 1965 r. w programie 5. Sesji znalazł się pierwszy artykuł omawiający wyniki badań nad integrowanym zwalczaniem szkodników buraków (Lipa 1965). Autor ocenił zdrowotność gąsienic błyszczki jarzynówki (Plusia gamma L.) oraz rolnicy panewki (Agrotis c-nigrum L.) oraz badał możliwość ograniczenia ich liczebności przez zastosowanie biopreparatów zawierających bakterię Bacillus thuringiensis Berliner.

Uwagę zwraca też referat Świętochowskiego (1965), w którym autor szczegółowo omówił różne koncepcje ograniczania zachwaszczenia upraw rolniczych nawiązując do integrowanego zwalczania szkodników. Było to pionierskie podejście do regulacji zachwaszczenia tym bardziej, że w tamtym okresie integrowaną ochronę kojarzono tylko ze zwalczaniem szkodników, a rozszerzenie tej koncepcji ochrony na wszystkie agrofagi miało miejsce znacznie później.

Dla rozwoju badań w zakresie integrowanej ochrony roślin w Polsce bardzo ważne znaczenie miały obrady 7. Sesji Naukowej Instytutu Ochrony Roślin, które odbyły się w lutym 1967 r. w Poznaniu.

We wprowadzającym do obrad Sesji referacie zatytułowanym „Dziś i jutro ochrony roślin” prof. W. Węgorek (1967) powiedział: „Chcąc przyszły kierunek rozwoju scharakteryzować możliwie krótką definicją użyć należy określenia „,integracja metod walki”. Jak wiadomo nowoczesna ochrona roślin dysponuje kilkoma metodami walki z chorobami, szkodnikami czy chwastami. Integracja więc metod walki polegać winna na łączeniu tych różnorodnych metod w jedną integralną całość". Dalej autor podkreślił, że temat integracji został uznany za szczególnie ważny i potrzebny, a do jego rozwiązania powołano w Komitecie Nauki i Techniki specjalny Zespół.

Prof. Węgorek stwierdził, że metody integrowane są trudne $\mathrm{w}$ prowadzeniu $\mathrm{i}$ istnieje potrzeba przystosowania praktyki rolniczej do wykonywania zabiegów terminowo, bardzo starannie, przy użyciu nowoczesnych środków i urządzeń, że przygotowanie producentów rolnych jest niewystarczające. Swoje wystąpienie prof. Węgorek zakończył zdaniem: „Chcę podkreślić, że nauka nasza znajduje się w czołówce krajów opracowujących te nowe drogi ochrony roślin. Jednakże jeśli wyniki prac mają przeniknąć do terenu i tam znaleźć zastosowanie to trzeba też stworzyć zaplecze, bo każdy postęp musi opierać się o bazę materialną".

Wystąpieniu prof. W. Węgorka towarzyszyły kolejne referaty omawiające: udział metod biologicznych w integrowanych programach ochrony (Lipa 1967), perspektywy stosowania integrowanych programów upraw warzywnych
(Narkiewicz-Jodko i Szwejda 1967), integrowaną metodę ochrony w sadach (Łęski 1967), a także bezpośrednio związane $\mathrm{z}$ integrowaną ochroną informacje dotyczące wpływu insektycydów na entomofaunę pożyteczną (Trojanowski 1967) oraz znaczenia systematyki w realizacji integrowanych programów ochrony (Boczek 1967).

Zasługuje na podkreślenie to, że w poszczególnych wystąpieniach autorzy oprócz zagadnień ogólnych omawiali wyniki badań wykonanych w Polsce. W zakresie biologicznego zwalczania szczególną uwagę zwrócono na znaczenie wrogów naturalnych w redukcji nasilenia szkodników, selektywne środki ochrony roślin oraz na nową koncepcję miejsca metody biologicznej, której celem miało być nie tyle zastępowanie metody chemicznej, co jej uzupełnianie. $\mathrm{Z}$ prowadzonych już badań na uwagę zasługują wyniki doświadczeń nad przydatnością biopreparatów zawierających bakterię $B$. thuringiensis w zwalczaniu gąsienic motyli, badania nad kruszynkiem, biedronkami i złotookami, a także odpornością odmian kapusty na bielinki (Pieris spp.) i mszyce kapuścianą (Brevicoryne brassicae L.). Narkiewicz-Jodko i Szwejda (1967) w zakończeniu referatu poświęconego integrowanej ochronie warzyw podali warunki, jakie należy spełnić w celu szerokiego zastosowania integrowanej ochrony, a mianowicie:

1) Wzbogacenie krajobrazu zarówno pod względem florystycznym, jak i faunistycznym oraz zabezpieczenie i wykorzystanie wrogów naturalnych szkodników.

2) Pełne wykorzystanie metod agrotechnicznych i hodowli odpornościowej.

3) Dobór do ochrony roślin warzywnych możliwie najmniej szkodliwych i selektywnych oraz szybko zanikających w środowisku preparatów chemicznych.

4) Stosowanie odpowiednich terminów i form zabiegów chemicznych ze zwróceniem głównej uwagi na zaprawienie nasion i doglebowe stosowanie preparatów.

5) Zwiększenie odporności roślin przez odpowiednią agrotechnikę i hodowle odpornościowe.

Zbieżność tych warunków z ogólnymi warunkami stosowania integrowanej ochrony roślin zawartymi w Załączniku III do Dyrektywy 2009/128/WE (Załącznik 2009) i w Rozporządzeniu Ministra Rolnictwa i Rozwoju Wsi w sprawie wymagań integrowanej ochrony roślin jest bezdyskusyjna.

Najbardziej zaawansowane w tym okresie w Polsce były badania prowadzone w sadach (Łęski 1967), a Polska należała do grupy krajów, w których już wtedy opracowano integrowane programy ochrony. Ten postęp był wynikiem bardzo wcześnie podjętych badań nad opracowaniem integrowanej ochrony sadów spowodowanych dużą liczbą zabiegów prowadzonych w sadach, wystąpieniem populacji szkodników odpornych na stosowane insektycydy, a także masowym wystąpieniem przędziorków w konsekwencji likwidacji w czasie zabiegów ich wrogów naturalnych.

Wzrost liczebności przędziorków po stosowaniu środków zawierających DDT zaobserwowano w Polsce już w 1949 r., a w roku 1965 stwierdzono wystąpienie populacji owocówki jabłkóweczki (Carpocapsa pomonella L.) odpornej na metoksychlor (Łęski 1967). 
W przedstawionych wystąpieniach zwracano uwagę na potrzebę lepszego poznania organizmów szkodliwych zagrażających uprawom, poznania agrocenoz i gatunków mających największe znaczenie w ograniczaniu liczebności agrofagów, ustalanie potrzeby wykonania zabiegu w oparciu o znajomość nasilenia agrofagów i progów ich szkodliwości, a także konieczność dobrego przygotowania służb doradczych do upowszechniania, a rolników do wdrożenia integrowanych programów ochrony.

Efektem obrad 7. Sesji Naukowej IOR był znaczny wzrost badań nad możliwością wykorzystania metody biologicznej, co przełożyło się na opracowanie i szerokie upowszechnienie stosowania metody biologicznej i programów integrowanych $\mathrm{w}$ ochronie upraw szklarniowych oraz doprowadzenie do podjęcia integrowanej produkcji owoców (Niemczyk 2002).

W 1971 r. w czasie 11. Sesji ważnym wydarzeniem było omówienie przez Głogowskiego (1971) podjętej w 1970 r. przez Radę Ministrów Uchwały Nr 64/70 z dnia 18 maja w sprawie organizacji badań w zakresie toksykologii i bezpiecznego stosowania pestycydów oraz kontroli ich pozostałości w żywności i środowisku życia człowieka. Na podstawie tej uchwały i dalszych podejmowanych decyzji stworzono w Polsce ogólnokrajowy system badania pozostałości środków ochrony roślin w produktach roślinnych i zwierzęcych oraz doprowadzono do wycofania ze stosowania substancji czynnych trwale zalegających w środowisku (związki dienowe, DDT, lindan, zaprawy rtęciowe), substancji niebezpiecznych $\mathrm{z}$ toksykologicznego punktu widzenia (chlorowane kamfeny, nitrofen, kaptafol, zineb) oraz środków pylistych stanowiących największe zagrożenie dla środowiska.

Był to milowy krok w kierunku ograniczenia zagrożeń, jakie może stwarzać dla ludzi i środowiska stosowanie chemicznej ochrony roślin, ale jednocześnie ważna decyzja dla rozwoju integrowanej ochrony roślin w naszym kraju.

Ewolucję pojęcia integrowana ochrona roślin i wprowadzenie w angielskim słownictwie określenia ,integrated pest management" omówił Lipa (1984) w czasie obrad 24. Sesji. Wcześniej Pruszyński (1982) przedstawił integrowaną ochronę upraw szklarniowych opartą na szerokim wykorzystaniu czynników biologicznych w ograniczaniu liczebności szkodników. Integrowaną ochronę sadów $\mathrm{w}$ połączeniu $\mathrm{z}$ integrowaną produkcją owoców przedstawił Niemczyk (2002) w czasie obrad 42. Sesji.

W programach 32. i 34. Sesji znalazły miejsce dwa bardzo ważne referaty dotyczące integrowanych programów ochrony zbóż (Pokacka 1992) oraz rzepaku ozimego (Pałosz i wsp. 1994). Na przedstawiony integrowany program ochrony rzepaku składały się: agrotechnika, ocena stanu fitosanitarnego uprawy, obecność wrogów naturalnych, szkodników oraz ustalenie terminów zabiegów zapewniających ochronę entomofauny pożytecznej. Był to program przygotowany dla potrzeb praktyki.

W programach 39., 40. i 41. Sesji znalazły się referaty Dąbrowskiego (1999, 2000, 2001) szeroko omawiające przyczyny niepowodzeń we wdrażaniu integrowanych programów ochrony upraw oraz warunki, jakie należy spełnić przystępując do upowszechnienia tych systemów ochrony. Były to ważne referaty szczególnie w obliczu spodziewanego wstąpienia Polski do Unii Europejskiej i zdecy- dowanego ukierunkowania ochrony roślin w Unii na jej bezpieczeństwo dla człowieka i środowiska. Należy przypomnieć tu preambułę Dyrektywy 91/414 (Dyrektywa 1991), w której napisano: „Ochrona zdrowia ludzi, zwierząt i środowiska ma pierwszeństwo przed poprawą poziomu produkcji rolniczej”.

Członkostwo Polski w Unii Europejskiej oraz ustalony Rozporządzeniem 1107/2009 (Rozporządzenie 2009) i Dyrektywą 2009/128/WE (Dyrektywa 2009) obowiązek wprowadzenia we wszystkich krajach Unii prowadzenia od stycznia 2014 r. ochrony roślin zgodnie z zasadami ochrony integrowanej znalazł swoje odbicie w programach kolejnych Sesji Naukowych IOR - PIB.

W programie 52. Sesji w 2012 r. Surawska omówiła „Krajowy Plan Działania na rzecz ograniczenia ryzyka związanego ze stosowaniem środków ochrony roślin na lata 2013-2018" (Krajowy Plan Działania 2013), a w dalszej części obrad plenarnych przedstawiono 12 referatów, których tematem były naukowe podstawy integrowanej ochrony roślin.

Rok później, w programie 53. Sesji znalazły się wystąpienia:

M. Surawska, B. Rzeźnicki - „Nowe przepisy prawne w ochronie roślin",

T. Kłos - „Zadania PIORiN w nadzorze nad integrowaną ochroną roślin",

D. Sosnowska i wsp. - „Rola nauki we wdrażaniu integrowanej ochrony roślin",

M. Mrówczyński i wsp. - „Integrowana ochrona roślin rolniczych - stan aktualny oraz perspektywy”.

Sympozjum Przedsesyjne organizowane przez IOR PIB i Komitet Ochrony Roślin PAN w roku 2013 było poświęcone „Biologicznym metodom $\mathrm{w}$ integrowanej ochronie roślin".

W trakcie 54. Sesji skupiono się na problemie zadań nauki we wdrażaniu integrowanej ochrony roślin. Wygłoszonych zostało 11 referatów omawiających m.in.: kontrolę integrowanej ochrony roślin, metodyki integrowanej ochrony roślin, znaczenie monitoringu, ekonomiczne progi szkodliwości, świadomość producentów, a także miejsce odmian modyfikowanych genetycznie w integrowanej ochronie roślin.

Znaczne wzbogacenie programów ostatnich trzech Sesji Naukowych IOR - PIB w tematykę dotyczącą integrowanej ochrony roślin było uzasadnione nie tylko ustanowionym przez Unię Europejską obowiązkowym wprowadzeniem integrowanej ochrony roślin, ale także ustaloną od wielu lat pozycją Sesji jako spotkań wpływających na przyspieszenie upowszechnienia nowych rozwiązań w ochronie roślin.

\section{Podsumowanie / Summation}

Powracając do tytułu tego opracowania jest on całkowicie zgodny ze zmianami w ochronie roślin, jakie miały miejsce w ciągu ostatnich 55 lat. Pierwsza konferencja dająca początek Sesjom Naukowym IOR odbyła się w czasie początku krytyki chemicznej ochrony roślin, ale przy powszechnym stosowaniu DDT i innych substancji czynnych z tej grupy chemicznej, a ostatnie Sesje Nauko- 
we to przygotowanie do wdrożenia i upowszechnienia integrowanej ochrony roślin. W trakcie ostatniej, 55. Sesji zostały omówione pierwsze wyniki realizacji tego systemu ochrony w Polsce. Z rozwojem koncepcji i strategii realizacji zadań ochrony roślin $\mathrm{w}$ naszym kraju (Olszak i wsp. 2000) Sesje Naukowe IOR przebyły długą drogę „Od DDT do integrowanej ochrony roślin”. Jaka była ich rola $\mathrm{W}$ stymulowaniu $\mathrm{i}$ upowszechnianiu postępu oraz przygotowaniu polskiej ochrony roślin do powszechnego wprowadzenia zasad integrowanej ochrony roślin? Odpowiedzi na to pytanie należy poszukiwać w przyjętej przez organizatorów Sesji nadrzędnej zasadzie, że mają one stanowić miejsce spotkania nauki i praktyki ochrony roślin przez bardzo liczny udział przedstawicieli administracji państwowej, pracowników służby ochrony roślin, przedstawicieli jednostek naukowych, producentów środków ochrony roślin, a także producentów rolnych. Sesje w pełni spełniły założenia organizatorów. W latach 60. XX wieku i później nie było jeszcze wykorzystywanych obecnie form przekazu, (internet, e-mail, bogata prasa fachowa) i spotkania Sesyjne były niezwykle istotnym elementem w upowszechnianiu wyników badań i ukierunkowywaniu rozwoju ochrony roślin w Polsce. Szczególnie podkreślić należy aktywny udział pracowników służby ochrony roślin, którzy przez przygotowywane wystąpienia oraz udział $w$ dyskusjach przedstawiali aktualne problemy praktyki ochrony roślin.

Sytuacja ta uległa niekorzystnej zmianie po roku 1990. Zmiana systemu dystrybucji środków ochrony roślin, rozwiązanie Państwowych Gospodarstw Rolnych i wresz- cie utworzenie na mocy Ustawy o ochronie roślin z $1995 \mathrm{r}$. Państwowej Inspekcji Ochrony Roślin, (obecnie i Nasiennictwa), wpłynęły na znaczne ograniczenie udziału w Sesjach przedstawicieli praktyki ochrony roślin. Nie bez znaczenia była tu pogarszająca się sytuacja ekonomiczna służb pracujących na rzecz rolnictwa i ochrony roślin.

Bezdyskusyjne jest natomiast podporządkowanie programów Sesyjnych potrzebom praktyki ochrony roślin i sukcesywne przekazywanie uczestnikom informacji o rozwoju integrowanej ochrony i warunkach jej upowszechniania. W tym przypadku rola Sesji jest niepodważalna i nieoceniona.

Przy zmianie zakresu zadań realizowanych przez Inspekcję Ochrony Roślin i Nasiennictwa obowiązki doradztwa w zakresie ochrony roślin przejmują na siebie Ośrodki Doradztwa Rolniczego, dotyczy to również prowadzenia rejestracji, sygnalizacji i prognoz występowania organizmów szkodliwych. W związku z powyższym liczny udział pracowników Doradztwa w Sesjach wydaje się być bardzo wskazany, tym bardziej, że nie wszystkie wygłaszane wystąpienia są publikowane, a nic przecież nie zastąpi bezpośrednich rozmów i dyskusji ze specjalistami.

Należy przypomnieć słowa wypowiedziane przez prof. W. Węgorka, że nie można liczyć na upowszechnienie nowości bez dobrze przygotowanych odbiorców. Te słowa są szczególnie aktualne obecnie, a udział w Sesjach Naukowych IOR - PIB jest ważnym krokiem w podniesieniu poziomu przygotowania zawodowego doradców i w konsekwencji producentów rolnych.

\section{Literatura / References}

Boczek J. 1967. Systematyka, a integrowane zwalczanie roztoczy. Biuletyn Instytutu Ochrony Roślin 36: 73-86.

Boczek J. 2010. Wspomnienia z Sesji Naukowych Instytutu Ochrony Roślin. s. 241-245. W: „50 lat Sesji Naukowych IOR (1961-2010)" (M. Mrówczyński, red.). Inst. Ochr. Roślin - PIB, Poznań, 324 ss.

Carson R.L. 1962. Silent Spring. Houghton Mifflin Company, New York. ISBN 978-014-118-49-44, 320 pp.

Dąbrowski Z.T. 1999. Znaczenie partnerskich powiązań przy opracowaniu i wdrażaniu integrowanych programów ochrony roślin. [The importance of partnership relations in developing and implementation of IPM programmes]. Progress in Plant Protection/Postępy w Ochronie Roślin 39 (1): 190-201.

Dąbrowski Z.T. 2000. Konieczność zmian metod w opracowywaniu i wdrażaniu integrowanych metod ochrony roślin. [The necessity of changes in the methodology of development and implementation of integrated pest management]. Progress in Plant Protection/Postępy w Ochronie Roślin 40 (1): 334-342.

Dąbrowski Z.T. 2001. Wskaźniki i kryteria oceny programów integrowanej ochrony roślin. [Indices and criteria used in the evaluation of integrated pest management programmes]. Progress in Plant Protection/Postępy w Ochronie Roślin 41 (1): $77-87$.

Dyrektywa 1991. Dyrektywa Rady z dnia 15 lipca 1991 roku dotycząca wprowadzania do obrotu środków ochrony roślin 91/414/EWG. Dz. U. L 230/1 z dnia 19.08.1991, s. 332.

Dyrektywa 2009. Dyrektywa Parlamentu Europejskiego i Rady 2009/128/WE z dnia 21 października 2009 roku ustanawiająca ramy wspólnotowego działania na rzecz zrównoważonego stosowania pestycydów. Dz. U. L 309/71 z 24.11.2009, s. 71.

Głogowski K. 1971. Zadania Instytutu Ochrony Roślin w świetle Uchwały Rady Ministrów Nr 64/70 z dnia 18 maja 1970 r. w sprawie organizacji badań w zakresie toksykologii i bezpiecznego stosowania pestycydów oraz kontroli ich pozostałości w żywności i środowisku życia człowieka. Biuletyn Instytutu Ochrony Roślin 50: 455-462.

Krajowy Plan Działania 2013. Krajowy Plan Działania na rzecz ograniczenia ryzyka związanego ze stosowaniem środków ochrony roślin. Monitor Polski, Dz. U. poz. 536 z dnia 18 czerwca 2013 r.

Ląkocy A. 1961. Rola wtórnego działania DDT w procesie powstania odporności owadów na insektycydy w świetle najnowszych badań nad stonką ziemniaczaną (Leptinotarsa decemlineata Say). Biuletyn Instytutu Ochrony Roślin 12: 37-56.

Lipa J.J. 1963. Chemiczne czy biologiczne metody ochrony roślin. Biuletyn Instytutu Ochrony Roślin 24: $213-228$.

Lipa J.J. 1965. Wstępne badania do integracji zwalczania szkodników buraków. Biuletyn Instytutu Ochrony Roślin 26: 395-407.

Lipa J.J. 1967. Udział metod biologicznych w integrowanych programach ochrony roślin. Biuletyn Instytutu Ochrony Roślin 36: 23-32.

Lipa J.J. 1984. Integrowanie metod zwalczania i sterowania populacjami agrofagów w nowoczesnych programach ochrony roślin. Materiały 24. Sesji Naukowej Instytutu Ochrony Roślin: 31-48.

Łęski R. 1967. Integrowane metody ochrony roślin w sadach. Biuletyn Instytutu Ochrony Roślin 36: 269-290.

Metcalf R.L. 1980. Changing role of insecticides in crop protection. Annual Review of Entomology 25: $291-256$. 
Mrówczyński M. (red.). 2010. 50 lat Sesji Naukowych IOR (1961-2010). Inst. Ochr. Roślin - PIB, Poznań, 324 ss.

Narkiewicz-Jodko J., Szwejda J. 1967. Perspektywy stosowania integrowanych metod ochrony roślin warzywnych. Biuletyn Instytutu Ochrony Roślin 36: 33-46.

Niemczyk E. 2002. Jedenaście lat integrowanej produkcji owoców w Polsce. [Eleven years of integrated fruit production in Poland]. Progress in Plant Protection/Postępy w Ochronie Roślin 42 (1): 33-38.

Olszak R.W., Pruszyński S., Lipa J.J., Dąbrowski Z.T. 2000. Rozwój koncepcji i strategii wykorzystania metod oraz środków ochrony roślin. [Development of the concepts and strategies of Plant Protection - methods and means]. Progress in Plant Protection/Postępy w Ochronie Roślin 40 (1): 40-50.

Pałosz T., Mrówczyński M., Muśnicki Cz. 1994. Podstawy integrowanej ochrony rzepaku ozimego przed szkodnikami. Materiały 34. Sesji Naukowej Instytutu Ochrony Roślin, cz. 1: 111-116.

Piekarczyk K. 1961. Geneza, podstawy naukowe oraz zasady organizacyjne prognoz i sygnalizacji w Polsce. Biuletyn Instytutu Ochrony Roślin 12: 301-328.

Pokacka Z. 1992. Integrowane programy ochrony w badaniach Instytutu Ochrony Roślin na przykładzie upraw zbóż. Materiały 32. Sesji Naukowej Instytutu Ochrony Roślin, cz. 1: 21-27.

Pruszyński S. 1982. Biologiczne i integrowane metody ochrony upraw szklarniowych przed szkodnikami - korzyści i perspektywy. Materiały 22. Sesji Naukowej Instytutu Ochrony Roślin: 293-308.

Pruszyński S., Moszczyński W. (red.). 1992. Produkcja i dystrybucja środków ochrony roślin. Raport o stanie i potrzebach ochrony roślin w Polsce. Inst. Ochr. Roślin, Poznań, 70 ss.

Rozporządzenie 2009. Rozporządzenie Parlamentu Europejskiego i Rady (WE) Nr 1107/2009 z dnia 21 października 2009 r. dotyczące wprowadzania do obrotu środków ochrony i uchylające dyrektywy Rady 79/117/EWG i 91/414/EWG. Dz. U. L 309/1 z dnia 24.11.2009, s. 1.

Stern V.M., Smith R.F., van den Bosch R., Hagch K.S. 1959. The integrated control concept. Hilgardia 29: 11-16.

Świętochowski B. 1965. Integracja biologicznych i chemicznych sposobów walki z chorobami i szkodnikami z punktu widzenia zwalczania chwastów. Biuletyn Instytutu Ochrony Roślin 26: 209-226.

Trojanowski H. 1967. Wpływ niektórych insektycydów na pożyteczną entomofaunę. Biuletyn Instytutu Ochrony Roślin 36: 55-73.

Węgorek W. 1967. Dziś i jutro ochrony roślin. Biuletyn Instytutu Ochrony Roślin 36: 9-22.

Załącznik III Dyrektywy 2009/128/WE. Ogólne zasady integrowanej ochrony roślin. Dz. U. L 309/85 z dnia 24.11.2009. 